\title{
Culturally Relevant Health Education: A Foundation for Building Cultural Competence of Health Professionals
}

\author{
Gail C. Frank ${ }^{1,4}{ }^{\oplus}$, Erika Centinaje $\mathrm{E}^{2,4}{ }^{\oplus}$, Natalia Gatdula $^{3,4}$, Melawhy Garcia $^{3,4}$, Selena T.

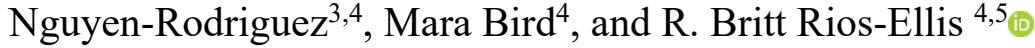 \\ ${ }^{l}$ Dept. of Family and Consumer Sciences, California State University, Long Beach, CA \\ ${ }^{2}$ Optimization and Training, The Permanente Medical Group, Inc., Santa Clara, CA \\ ${ }^{3}$ Department of Health Science, California State University, Long Beach, CA \\ ${ }^{4}$ Center for Latino Community Health, Evaluation and Leadership Training, California State University \\ Long Beach, CA \\ ${ }^{5}$ Oakland University, Rochester, MI
}

\begin{abstract}
Background and Purpose: Professionals educating ethnic minority populations should employ a cultural focus during development, training, refinement and implementation stages of an intervention. This manuscript posits that the skill of developing a culturally relevant curriculum supports the increase of cultural competence proficiency of professionals, while promoting health equity. Methods: A communitybased participatory research-trained staff recruited 378 families with 2 to 8 -year-old children. Eight intergenerational focus groups were conducted at neighborhood facilities. Graduate fellows conducted reviews of literature and health directives to conceptualize the curriculum. Spanish-speaking students and promotoras (community health workers) having participants' confidence, presented healthy lifestyle information and taught practical skills to each group of 12-16 low-income Latino families from Long Beach, CA. Results: With attention to participants' preferred language, educational level, cultural beliefs, practices and food preferences, the intervention demonstrates a culturally relevant curriculum. Hands-on activities and motivational interviewing questions enriched the 4-hour intervention delivered in Spanish. Graduate fellows' cultural competence increased. More than $97 \%$ of participants reported sessions beneficial to their families' health with $84 \%$ attending all sessions/assessments. Participants found the content easy to understand and helpful to eat healthier and be more active. Conclusion: Sanos y Fuertes is a model for developing a culturally relevant, family-based healthy lifestyle educational curriculum and building culturally competent health professionals.

(C) 2021 and CC-BY 4.0 licensed by the authors.

Keywords: culturally relevant curriculum, working groups, community health workers, participant-focused

\section{Introduction}

Cultural competence is an important aspect of curriculum development for health education professionals (National Commission for Health Education Credentialing, 2006). U.S. healthcare has identified health equity for ethnic minority

populations since first appearing as a Healthy People 2010 goal with training of interprofessionals (National Center for Health Statistics, 2012). Maximizing cultural relevance of interventions supports health equity but demands experiential training for professionals to increase their skills addressing a target audience's
\end{abstract}


health knowledge, language, economics, cultural beliefs and practices.

Latinos are twice as likely as whites to live below the federal poverty level (Economic Policy Institute, 2020). Poor nutrition, reduced years of education and disengagement occur within lowincome families compounding a high risk of overweight among children persisting into adulthood (Hsieh et al., 2015).

A certified health education specialist (CHES) investigator for Sanos y Fuertes (Healthy and
Strong) incorporated many of the standards of responsibility for certified health educators, Table 1, employing a person-centered approach and embedding motivational interviewing (MI) techniques. A previous publication described the program design and results (Frank et al., 2020). This manuscript details the curriculum development as a stepwise process not only defining and strengthening staff cultural competence but also promoting skills among Latino families.

Table 1.

Creation of the Sanos y Fuertes Curriculum and Link with Sub-Competencies of the Seven Areas of Responsibility for Health Education Specialists*

\begin{tabular}{lllll}
\hline Development & Practice & Refinement & Implementation & Evaluation \\
& & & & \\
\hline $1.5 .1-1.5 .4,1.6 .3-1.6 .5$, & 2.3 .4$, & 2.3 .4$, & $1.5 .1-1.5 .4,2.3 .4$, & $1.7 .4,2.3 .10-2.4 .10,3.2 .7-3.2 .8$, \\
$1.7 .3,2.3 .4,2.3 .5,3.3 .2$, & $3.2 .1-$ & 2.3 .10$, & $2.3 .6-2.3 .10$, & $3.4 .1-3.4 .3,3.4 .8,4.1 .1,4.1 .2$, \\
$4.2 .1,4.2 .3-4.2 .4,4.2 .9$, & 3.2 .6$. & 2.4 .3$. & $2.4 .4,3.1 .1-3.1 .2$, & $4.1 .3,4.1 .6,4.1 .8-4.1 .10,4.2 .12$, \\
$4.2 .11,4.2 .14,5.2 .1-5.2 .3$, & & & $3.1 .5,3.3 .3-3.3 .4$, & $4.3 .1-4.3 .7,4.3 .9-4.3 .10,4.4 .1-$ \\
$5.6 .1,5.6 .5,5.6 .11,5.6 .14$. & & & 3.3 .6 & $4.4 .5,4.5 .1-4.5 .5,4.6 .1,4.7 .5$.
\end{tabular}

* Seven Areas - Area 1: Assess Needs, Resources and Capacity, II: Plan Health Education/Promotion, III: Implement Health Education/Promotion, IV: Conduct Evaluation and Research, $\boldsymbol{V}$ : Administer and Manage Health Education, VI: Serve as a Resource, VII: Communicate, Promote and Advocate. Leadership and Management, designated as VIII Area: Ethics and Professionalism, will be effective with the 2022 exam. Source: National Commission on Health Education Credentialing, Inc., 2006. Seven Areas of Responsibility. http://ftp.nchec.org/forms/Revised_Areas_of_Responsibility.pdf

\section{Methods}

\section{Study Design}

Sanos y Fuertes (SyF) was developed using a mixed method design for relevance to Latino families in Long Beach, CA. The mixed model identified three primary tasks which were to identify the health education responsibilities, the curriculum topics/content, and the intervention timeline. The operational or managerial framework evolved as working groups each with a clearly defined purpose with sequential but often overlapping actions to accomplish what became five specific stages. These stages were to develop nutrition and lifestyle content, to practice and refine components for clarity of content increasing potential retention of participants, to train for improved delivery, to implement consistently over the grant period, and to evaluate effectiveness with behavioral and anthropometric measures. National Commission on Health Education Credentialing, Inc. responsibilities were matched to working group actions, for example, conducting focus groups, specifying literature research topics for Graduate Research Fellows (GRFs), placing promotoras' (community health workers) in leadership roles, embedding open-ended questions with a decision-making ruler, and outlining skillbuilding activities (National Commission for Health Education Credentialing, 2006). 
With no standardized outline to follow, the grant came to life as professional knowledge, leadership and collaboration drove weekly/biweekly meeting agenda for the working groups implementing 5-stage process, Table 2. This process was essential for creating the intervention charla (health education session), increasing knowledge and confidence among participants, and transitioning knowledge into practice.

The curriculum became a healthy lifestyle, interactive intervention comprised of eight topics over 4-hours with hands-on learning activities (Frank et al., 2013).

\section{Procedures}

Curriculum Content Development for Staff. A multi-cultural research/leadership team attended weekly working group meetings, which included four promotoras and a cohort of seven bilingual Latino GRFs selected annually and majoring in social work, nutrition, or community health education, Table 2. Simultaneously, based on Bandura's Social Cognitive Theory, staff discussions considered dynamic personal, behavioral, and environmental factors precipitating behaviors (Bandura, 2004) identifying key style issues (topic, message content, text appearance, visuals, layout/design, translation, and understandability) and participant characteristics, e.g., gender, race/ethnicity, location, beliefs, behaviors, culture, literacy skills, and audience knowledge (Dietary Guidelines Advisory Committee, 2020). Eight separate intergenerational focus groups with 68 adults total and two with 22 youth total (with a maximum of 12 participants) included grandparents, parents and youth 10-to-17 years old. Responses revealed cultural perceptions of weight, e.g., positive view of plump/overweight in small children, lack of nutrition-related knowledge, permissive parenting, and concerns about obesity risk. Focus group results influenced curriculum topics: economic barriers, generational differences in food preference/preparation, limit of nutrition knowledge, need for parental role modeling of physical activities and healthful eating, and challenging cultural perceptions of weight and attitudes as related to eating (Garcia et al., 2019). Graduate Research Fellows (GRFs) reviewed literature, national directives for food, movement and educational materials, e.g., 'Dietary Guidelines for Americans' and 'Recommended Dietary Allowances', creating an artistic, lowliteracy $\left(6^{\text {th }}\right.$ grade level), and easy-to-use curriculum for children and mothers. Additionally, GRFs' responsibilities included note-taking and transcribing focus group recordings, leading charlas, collecting and entering data.

Implementation Practice. Over the initial 6month period, promotoras and GRFs presented to staff, reviewed and edited educational materials followed by training activities ranged from roleplaying both focus group conduct to checkin/consenting dialogues to Spanish transcreation and practice.

Refinement of Curriculum. As topics were clarified with practice, working groups, comprised of seven GRFs, four promotoras and four staff, rehearsed final sessions with the goal of presenting them each in 20-30 minutes sessions. Each session was created with artistic PowerPoint slides that provided culturally relevant visuals and activity sheets. A standard format was defined for each topic, i.e., introduction; health-related facts; sources; link between food and health; motivational interviewing (MI) questions for discussion, selfefficacy and behavioral intent; a brief Q\&A; and a skill-development activity, Table 3 . 
Table 2.

Graduate Research Fellows and Promotoras Activities in the Sanos y Fuertes Curriculum

\begin{tabular}{|c|c|c|c|c|c|}
\hline Activity & Development & Practice & Refinement & $\begin{array}{l}\text { Implementa- } \\
\text { tion }\end{array}$ & Evaluation \\
\hline $\begin{array}{l}\text { 8-Focus } \\
\text { Groups }\end{array}$ & $\begin{array}{l}\text { Results from focus } \\
\text { groups (FGs) } \\
\text { informed the } \\
\text { curriculum } \\
\text { approach. }\end{array}$ & $\begin{array}{l}\text { Organized } \\
\text { questions: } \\
\text { knowledge, } \\
\text { attitudes, } \\
\text { barriers, } \\
\text { healthful } \\
\text { eating and } \\
\text { children's } \\
\text { weight. }\end{array}$ & $\begin{array}{l}\text { Chose final } \\
\text { questions: } \\
\text { SES barriers; } \\
\text { generational food } \\
\text { preference; } \\
\text { parental role; } \\
\text { perceptions of } \\
\text { weight. }\end{array}$ & $\begin{array}{l}\text { Conducted } 8 \\
\text { FGs in Spanish; } \\
\text { recorded and } \\
\text { prepared written } \\
\text { notes. }\end{array}$ & $\begin{array}{l}\text { Quantitative surveys } \\
\text { assessed socio- } \\
\text { demographics, cultural and } \\
\text { family characteristics, } \\
\text { health care access, eating } \\
\text { behavior and activity to } \\
\text { supplement qualitative } \\
\text { findings. }\end{array}$ \\
\hline $\begin{array}{l}\text { Literature (lit.) } \\
\text { Review }\end{array}$ & $\begin{array}{l}\text { Graduate research } \\
\text { fellows (GRFs) } \\
\text { conducted lit. } \\
\text { reviews for } \\
\text { evidence-based } \\
\text { topics and } \\
\text { participant- } \\
\text { centered } \\
\text { approach.** }\end{array}$ & $\begin{array}{l}\text { GRFs } \\
\text { assigned } \\
\text { topics; } \\
\text { reviewed } \\
\text { credible } \\
\text { federal } \\
\text { websites and } \\
\text { peer-reviewed } \\
\text { publications. }\end{array}$ & $\begin{array}{l}\text { GRFs presented } \\
\text { outlines and received } \\
\text { feedback from } \\
\text { program staff. } \\
\text { Incorporated latest } \\
\text { guidelines on } \\
\text { nutrition and physical } \\
\text { activity. }\end{array}$ & $\begin{array}{l}\text { GRFs were } \\
\text { instructed to cite } \\
\text { all sources used } \\
\text { in curriculum } \\
\text { development. }\end{array}$ & $\begin{array}{l}\text { GRFs developed } \\
\text { PowerPoint slides and } \\
\text { received feedback. }\end{array}$ \\
\hline $\begin{array}{l}\text { Graduate } \\
\text { Research } \\
\text { Fellows' } \\
\text { (GRFs) } \\
\text { Focus Areas }\end{array}$ & $\begin{array}{l}\text { Cohorts } 1 \text { and } 2 \\
\text { worked closely } \\
\text { with staff on } \\
\text { nutrition topics } \\
\text { inserting reputable } \\
\text { sources. }\end{array}$ & $\begin{array}{l}\text { Content was } \\
\text { developed in } \\
\text { English and } \\
\text { transcreated } \\
\text { into Spanish. }\end{array}$ & $\begin{array}{l}\text { Pilot-tested and } \\
\text { revised. Cohorts } \\
3,4,5 \text { ensured } \\
\text { understanding. } \\
\text { Cohort } 4 \text { chose } \\
\text { photos for adult \& } \\
\text { children. }\end{array}$ & $\begin{array}{l}\text { Several } \\
\text { hours/week } \\
\text { assigned to } \\
\text { address focus } \\
\text { area activities. }\end{array}$ & $\begin{array}{l}\text { Curriculum revision tracker } \\
\text { identified progressive } \\
\text { changes to curriculum } \\
\text { recording slide number and } \\
\text { minor changes. }\end{array}$ \\
\hline Promotoras & $\begin{array}{l}\text { Trans-created } \\
\text { content from } \\
\text { English to Spanish } \\
\text { for respectful \& } \\
\text { clear words. }\end{array}$ & $\begin{array}{l}\text { Attended all } \\
\text { meetings \& } \\
\text { curriculum } \\
\text { practices. }\end{array}$ & $\begin{array}{l}\text { Pilot-tested and } \\
\text { revised. } \\
\text { Trained in public } \\
\text { speaking \& } \\
\text { presentation style by } \\
\text { program staff. }\end{array}$ & $\begin{array}{l}\text { Delivered the } \\
\text { curriculum with } \\
\text { GRFs in } \\
\text { Spanish. }\end{array}$ & $\begin{array}{l}\text { Regularly provided } \\
\text { feedback/suggestions for } \\
\text { improvement on curriculum } \\
\text { delivery at project } \\
\text { meetings. }\end{array}$ \\
\hline $\begin{array}{l}\text { Dietary } \\
\text { Guidelines } \\
\text { for Americans } \\
\text { critiqued }\end{array}$ & $\begin{array}{l}\text { Comprised basic } \\
\text { nutrition } \\
\text { information } \\
\text { presented to GRFs } \\
\text { and promotoras. }\end{array}$ & $\begin{array}{l}\text { Revised to } \\
\text { assure } \\
\text { simplicity of } \\
\text { presentation. }\end{array}$ & $\begin{array}{l}\text { Pilot-tested and } \\
\text { revised. } \\
\text { FAQ developed from } \\
\text { each charla for } \\
\text { common questions. }\end{array}$ & $\begin{array}{l}\text { Some of the } \\
\text { questions of } \\
\text { participants } \\
\text { became part of } \\
\text { clarifying } \\
\text { content. }\end{array}$ & $\begin{array}{l}\text { Assured relevant to skill- } \\
\text { building. }\end{array}$ \\
\hline
\end{tabular}

** Centers for Disease Control and Prevention. U.S. Department of Health and Human Services.

Simply Put - A guide for creating easy-to-understand materials. $3^{\text {rd }}$ Ed. Atlanta, GA. April 2009

English text was visible on the left side of each slide and Spanish on the right. Printed pages of the PowerPoint slides were placed in a binder/toolkit with instructive information to guide GRFs and promotoras during the charla. Ten-minute, hands-on activities included, for example, using measuring utensils to portion foods onto a paper model of MyPlate/MiPlato, or choosing the healthiest option by comparing salt, sugar and fat content of food pairs. The objective of each activity was to increase participants' understanding, confidence, and intention for the activity to become their habitual behavior. 
Table 3.

Skill-Building Activities in the Sanos y Fuertes Curriculum

\begin{tabular}{|l|l|l|l|l|l|}
\hline $\begin{array}{l}\text { Skill-building } \\
\text { Activities }\end{array}$ & $\begin{array}{l}\text { Hands-on activities based } \\
\text { on evidence-based } \\
\text { practices identified in the } \\
\text { lit. Developed: MyPlate / } \\
\text { MiPlato, food label, } \\
\text { shopping, food portions, } \\
\text { physical activities. }\end{array}$ & $\begin{array}{l}\text { Reviewed for ease } \\
\text { in delivery and } \\
\text { reflecting skills } \\
\text { needed to promote } \\
\text { healthy family } \\
\text { foods and meals. }\end{array}$ & $\begin{array}{l}\text { Pilot-tested and } \\
\text { revised for final } \\
\text { implementation. } \\
\text { Revised during the } \\
\text { first year. }\end{array}$ & $\begin{array}{l}\text { Assured } \\
\text { worksheets and } \\
\text { instructions were } \\
\text { clear and simple } \\
\text { irrespective of the } \\
\text { age and education } \\
\text { of the mothers. }\end{array}$ \\
\hline $\begin{array}{l}\text { Staff } \\
\text { meetings } \\
\text { routinely } \\
\text { conducted }\end{array}$ & $\begin{array}{l}\text { Held to discuss content } \\
\text { areas for development } \\
\text { based on focus group } \\
\text { findings and research. }\end{array}$ & $\begin{array}{l}\text { Ongoing meetings, } \\
\text { multiple pass thru } \\
\text { process, setting } \\
\text { timelines, } \\
\text { reviewing progress } \\
\text { \& sealing content. }\end{array}$ & $\begin{array}{l}\text { Scheduled for GRFs } \\
\text { to present } \\
\text { preliminary work } \\
\text { and to receive } \\
\text { feedback and make } \\
\text { decisions. }\end{array}$ & $\begin{array}{l}\text { Final revisions } \\
\text { were based on } \\
\text { attention to } \\
\text { cultural beliefs, } \\
\text { common practices } \\
\text { and family- } \\
\text { approach. }\end{array}$ & $\begin{array}{l}\text { Process } \\
\text { evaluation } \\
\text { included minutes } \\
\text { of attendance } \\
\text { and decisions } \\
\text { made when a } \\
\text { difference of } \\
\text { opinion } \\
\text { occurred. }\end{array}$ \\
\hline $\begin{array}{l}\text { MI } \\
\text { Techniques }\end{array}$ & To assess mothers & $\begin{array}{l}\text { To facilitate } \\
\text { conversation in a } \\
\text { group setting. }\end{array}$ & $\begin{array}{l}\text { Pilot-tested and } \\
\text { revised for final } \\
\text { implementation. }\end{array}$ & $\begin{array}{l}\text { Presented in } \\
\text { Spanish \& placed } \\
\text { in curriculum. }\end{array}$ & $\begin{array}{l}\text { Pretested by } \\
\text { staff. }\end{array}$ \\
\hline
\end{tabular}

MI staff training included practicing questions to facilitate conversation and using a number line to gauge confidence of participants and to uncover/assess both their readiness for change and the need to reinforce their intrinsic motivation for change, Table 4. Any follow-up questions asked by actual participants were aggregated, researched and formed a standardized FAQ document for use throughout the intervention. In total, the curriculum intervention and evaluation timeline encompassed 4 of the 5-year grant award years.

Implementation. Weekly, on a Thursday or Friday from 6-8 p.m., 12-16 participants (primarily mothers) attended a consenting and baseline data collection session followed by a 4hour Saturday curriculum plus meals from 9 a.m.2 p.m. A \$25 gift card incentive was given per assessment point. Promotoras and GRFs demonstrated dignity/respect for cultural pride, health beliefs, and familism when conducted the intervention, providing meals, snacks and physical activities. Infant childcare and classes for 3 to 8 -year-old children were available in rooms adjacent/open to the mothers. Free parking and teaching in a building close to bus lines made access convenient and participation possible. The final curriculum, influenced by pre-existing curricula and national guidelines, had nine modules, i.e., Importance of Breakfast, Overview of Overweight and Obesity, MyPlate and Portions, Nutrition Labels, Sweetened Beverages, Benefits of Planning for Grocery Store Shopping, Sedentary Behavior, Physical Activity, and Parental Role Modeling. GRFs assisted by teaching different modules and gained hands-on experience.

\section{Analyses}

Intervention participants completed evaluations at baseline, immediately after the last charla session, and at follow up 3-months after intervention. Evaluation surveys assessed knowledge, confidence, intentions, diet and activity levels to measure program effects. 
Table 4.

Motivational Interviewing Counseling During Charla

\begin{tabular}{|c|c|c|}
\hline Topic & Open-Ended Questions* - Partial Listing & Follow-up Question** \\
\hline Grains & $\begin{array}{l}\text { What are... } \\
\text { • whole grains? } \\
\text { • Challenges...benefits of eating more whole grains? } \\
\text { What changes can you make in your families' eating plan? }\end{array}$ & $\begin{array}{l}\text {... that you can include } \\
\text { more whole grains in your } \\
\text { family's eating plan? }\end{array}$ \\
\hline $\begin{array}{l}\text { Fruits and } \\
\text { vegetables }\end{array}$ & $\begin{array}{l}\text { What are... } \\
\text { - } \quad \text { some fruits and vegetables? } \\
\text { - Challenges...benefits of eating more? } \\
\text { What changes can you make in your families' eating plan? }\end{array}$ & $\begin{array}{l}\text {... that you can follow the } \\
\text { recommendations \& include } \\
\text { more fruits and vegetables? }\end{array}$ \\
\hline Food Labels & $\begin{array}{l}\text { What... } \\
\text { - does the label say? } \\
\text { - } \text { are examples of foods with little or no nutrients, i.e. junk } \\
\text { foods? } \\
\text { - Is a high sodium level? ... a low sodium level? } \\
\text { Where... } \\
\text { - } \\
\quad \text { in the food label? }\end{array}$ & $\begin{array}{l}\ldots \text { in your ability to read } \\
\text { food labels? }\end{array}$ \\
\hline Sugar & $\begin{aligned} & \text { What... } \\
& \text { - does "sugarless" mean? } \\
& \text { - } \\
& \quad \begin{array}{l}\text { are some suggestions you have for healthier, unsweetened } \\
\text { beverages? }\end{array}\end{aligned}$ & $\begin{array}{l}\text { How important is it to you } \\
\text { to reduce your family's } \\
\text { sugar intake? }\end{array}$ \\
\hline $\begin{array}{l}\text { Grocery } \\
\text { Shopping }\end{array}$ & $\begin{array}{l}\text { Who does the grocery shopping in the family? } \\
\text { What ... } \\
\text { - do you have on hand? ...do you need? } \\
\text { How ... is one strategy for involving children in shopping? } \\
\text { - do you shop for groceries? } \\
\text { - often do you make a list? }\end{array}$ & $\begin{array}{l}\text { How confident are you that } \\
\text { you will plan ahead when } \\
\text { going grocery shopping? }\end{array}$ \\
\hline $\begin{array}{l}\text { Physical } \\
\text { Activity }\end{array}$ & $\begin{array}{l}\text { What is Sedentary Behavior? } \\
\text { How ... } \\
\text { - do you keep your body healthy? } \\
\text { - can you change your routine to add more exercise to your day? }\end{array}$ & $\begin{array}{l}\text { How important is it to you } \\
\text { to decrease screen time and } \\
\text { increase the physical } \\
\text { activity for you and your } \\
\text { family? }\end{array}$ \\
\hline \multicolumn{3}{|c|}{$\begin{array}{l}\text { * Adapted from Frank, G.C., Garcia-Vega, M., Ortega, E., \& Rios-Ellis, B. (2013). Reducing Obesity Risk by } \\
\text { Addressing Breastfeeding with Latina Moms Using Motivational Interviewing Techniques. Adelante LAHIDAN. } \\
\text { Fall/Winter, 5(1):3-6. } \\
\text { ** Follow-up questions using the MI Ruler to Gauge Confidence** 0-10 scale. 'How confident are you } \\
\text {,.'. GRF/Promotoras response: If 0-3, in follow-up, ask: What can you do to increase this number? If 4-6, re- } \\
\text { affirm: Oh, good. Then in follow-up, ask: What gives you that confidence? If 7-10, re-affirm: That's great that you } \\
\text { feel so confident. Then in follow-up, ask: What things can you do to keep this confidence? }\end{array}$} \\
\hline
\end{tabular}

Descriptive statistics provided participants' evaluation of program content, while repeated samples ANOVAs and paired t-tests assessed changes across assessment points.
Process evaluation involved weekly 'check-ins' with staff about leader activities to ensure project progress and quality control. GRFs completed baseline, post and follow-up assessments to gauge increases in knowledge, skills and program 
evaluation. Paired t-tests assessed changes in GRFs' cultural competence.

\section{Results}

Successful creation of a culturally relevant curriculum rested with the multi-cultural, dedicated staff and with the promotoras and GRFs who specifically mirrored the culture of the participants, building trust at all contact points. A structure for develop/communication was defined and served as the blueprint for fidelity of the curriculum. GRF's knowledge significantly increased about influences on Latino health $(\mathrm{MD}=0.98 ; \mathrm{t}=-7.66, \mathrm{p}<.001)$ and on culturally congruent health education including both knowledge of research methods $(\mathrm{MD}=1.68$; $\mathrm{t}=-$ $11.84, \mathrm{p}<.001)$ as well as skills for addressing community needs $(\mathrm{MD}=1.14 ; \mathrm{t}=-7.40, \mathrm{p}<.001)$. Significant increases were noted in the GRFs' confidence when working on a team to plan a culturally relevant intervention $(\mathrm{MD}=23.07$; $\mathrm{t}=$ $5.31, \mathrm{p}<.001$ ), to create a culturally relevant community curriculum $(\mathrm{MD}=28.59 ; \mathrm{t}=-7.93$, $\mathrm{p}<.001$ ), to help prevent obesity in Latino communities $(\mathrm{MD}=21.51 ; \mathrm{t}=-6.38, \mathrm{p}<.001)$ and to work as part of a team to solve a community need $(\mathrm{MD}=12.96 ; \mathrm{t}=-5.72, \mathrm{p}<.001)$.

All measurements at baseline and 3-months follow-up were completed by 328 of 378 Latinas yielding an $86.7 \%$ completion rate and significant changes published elsewhere (Frank et al., 2020). GRFs and promotoras implemented the charla to a $99 \%$ female sample $\left(\mathrm{M}_{\mathrm{age}}=35.80 \pm 6.66\right.$ years; $66.2 \%$ having less than a high school diploma/GED, 95.7\% living in severely crowded homes, $29.6 \%$ overweight and $53.4 \%$ obese); their children averaged $4.72 \pm 1.95$ years old with $15.6 \%$ overweight and $30.1 \%$ obese (Frank et al., 2020). Regarding the session information, $97.3 \%$ of participants agreed the charla was easy to understand, $97.9 \%$ agreed the charla would help their family to eat healthier, and $97.9 \%$ agreed it would help them be more active.

\section{Discussion}

Staff recognized and demonstrated the importance of linking curriculum content to the unique needs and practices of the target audience yielding high participant engagement. This reflected a positive, caring and trusting environment created by the promotoras and GRFs and highlights the impact an educational/behavioral intervention can have when astute to cultural beliefs and practices. Latino parents and children were receptive and given the high participation, it is believed participants felt staff were sensitive to their needs and eliminated common barriers by providing free childcare for siblings of the index child, culturally pleasing foods, and a gift card incentive. Concomitant classes for children reinforced a family-based approach including healthy meal decision-making for skill development.

Using in-depth, semi-structured interviews to explore processes among twenty-two Latino mothers in families with children ages 5-10 years living in Central Valley California, Sawyer and colleagues (Sawyer et al., 2019) identified influential food decision approaches with maternal beliefs spearheading all practices, but the two primary influences were 'traditional health' $(n=7)$ emphasizing eating favorite recipes and 'health of parent' ( $n=6)$ (Sawyer et al., 2019). Supporting this observation, favorite recipes with popular flavors were used in SyF to teach mothers about accurate portions promoting the health of all family members while demonstrating strategies to incorporate children when planning, shopping, and preparing family meals. GRFs modeled positive behaviors by embracing the lessons and their experiential learning not only fostered sustainability of the program but also strengthened their own cultural competence.

Specific responsibilities of health educators were central to the SyF development. From the conduct of focus groups and evidenced-based literature reviews of healthy foods and physical 
activities to creating easily understood instructive information for daily activities. This moved the needle both towards a cultural-relevant curriculum and cultural competence of staff.

Intervention outcomes noted that although no significant decrease was noted in parents' adiposity estimates, their body weight remained stable, changes in the frequency of sugary beverage, child fruit and vegetable intakes were small and in the right direction (Frank et al., 2020). An observed decline in children's percent body fat was observed and suggests parental application of knowledge to food intentions and behaviors may have influenced their child's health and a lowered body weight. Given the brevity of the intervention, any movement toward activities becoming routine, greatly increases long-term improvements in dietary intake and physical activity reducing health disparities and chronic disease progression.

\section{Limitations}

The lack of a control group prevents attributing changes only to the charla. Self-reported survey data may have been affected by recall bias and social desirability. Given that $86.5 \%$ of participants were born in Mexico, generalizability to other Latino heritage groups is not possible. However, SyF demonstrates maximum attention to culturally relevant lifestyle factors germane to the pan-Latino community.

\section{Conclusion}

In summary, development of a culturally relevant curriculum is a key skill in the pathway to building cultural competence of healthcare professionals. The evolution can begin with a mixed model design involving working groups with defined responsibilities and progress to addressing participants' preferred language, education, cultural beliefs and health needs across generations in the living environment. This requires addressing food preferences and can be demonstrated by embedding cultural foods and practices into a respectful, motivational teaching/learning format. As a result, SyF is a positive blueprint for developing a culturally relevant program.

\section{References}

Bandura, A. (2004). Health promotion by social cognitive means. Health Education and Behavior, 31(2), 143-164. doi: 10.1177/1090198104263660.

Dietary Guidelines Advisory Committee. (2020). Scientific Report of the 2020 Dietary Guidelines Committee: Advisory Report to the Secretary of Agriculture and the Secretary of Health and Human Services. U.S. Department of Agriculture, Agricultural Research Service, Washington, DC. website, https://www.dietaryguidelines.gov/sites/default/files/202007/ScientificReport of the 2020DietaryGuidelinesAdvisoryCommittee first-print.pdf

Economic Policy Institute. By the numbers - Income and Poverty, 2019. website, https://www.epi.org/blog/by-the-numbers-income-and-poverty2019/\#: : :text=Median $\% 20$ household $\% 20$ income $\% 20$ for $\% 20$ white, than $\% 20$ it $\% 20$ was $\% 20 \mathrm{in} \% 20$ 2000

Frank, G.C., Beaudoin, J., Rascón, M., \& Rios-Ellis B. (2013). Development of a culturally relevant nutrition promotion course for Latinos. Journal of the American Association of Family and Consumer Sciences, 105(1), 10-17. doi: 10.14307/jfcs105.1.5

Frank, G.C., Nguyen-Rodriguez, S.T., Bird, M., Garcia, M., Gatdula, N., Centinaje, E., Rascón, M., \& Rios-Ellis. B. (2020). Primary outcomes of a healthy lifestyle intervention for Latino families. Californian Journal of Health Promotion, 18(1), 29-38. doi: 10.32398/cjhp.v18i1.2452

Garcia, M.L., Gatdula, N., Bonilla, E., Frank, G.C., Bird, M., Rascón, M., \& Rios-Ellis, B. (2019). Engaging intergenerational Hispanic/Latinos to examine factors influencing childhood obesity 
using the PRECEDE-PROCEED model. Maternal and Child Health Journal, 23, 802-810. doi: 10.1007/s10995-018-02696-y

Hsieh, Y.-C., Apostolopoulos, Y., Hatzudis, K., \& Sönmez, S. (2015). Social, occupational, and spatial exposures and mental health disparities of working-class Latinas in the US. Journal of Immigrant and Minority Health, 18(3), 589-599. doi: 10.1007/s10903-015-0231-z

National Commission on Health Education Credentialing, Inc. (2006). Seven Areas of Responsibility. website, http://ftp.nchec.org/forms/Revised_Areas_of_Responsibility.pdf

National Center for Health Statistics. (2012). Healthy People 2010 Final Review. Hyattsville, MD. https://www.cdc.gov/nchs/data/hpdata2010/hp2010 final review.pdf

Sawyer, M., Sawyer, M., Duran, N. \& Wallace, S. (2019). Exploring food decision processes of Latino families in California's Central Valley. Californian Journal of Health Promotion, 17(1), 31-44. website, https://www.cdc.gov/nchs/healthy_people/hp2010/hp2010_final_review.htm

\section{Acknowledgements}

This study was supported by the United States Department of Agriculture, grant number 2011-6700230152. We extend a posthumous appreciation to Concepcion Garcia, one of the four original promotoras whose love and labors gave life to all aspects of the program and to Avery Goldstein, $\mathrm{PhD}$, Associate Professor, who was part of the original curriculum planning team, contributing to the family focus group design. We recognize the three other magnificent promotoras de salud who were the foundation of our success: Maria Cristina Chaple, Virginia Mata, and Maricela Parga. The research and implementation team at CSULB worked closely with the Center for Latino Community Health, Evaluation and Leadership Training, its staff and graduate students, community partners, and the gracious participant families who made this project possible.

Corresponding Author Information

Gail C. Frank -

1250 Bellflower Blvd.,

Long Beach, CA 90840-0501

562-985-4494.

Gail.Frank@csulb.edu 